\title{
Değişim Eğilimleri Ölçeğinin Geliştirilmesi
}

\author{
Doç. Dr. Sadegül Akbaba Altun \\ Başkent Üniversitesi, Eğitim Fakültesi, \\ Eğitim Bilimleri Bölümü Psikolojik Danışmanlık ve Rehberlik A.B.D. \\ Oda No: B119, 06530 Ankara / Türkiye
}

\begin{abstract}
Prof. Dr. Şener Büyüköztürk*
Gazi Üniversitesi, Gazi Eğitim Fakültesi, Eğitim Bilimleri Bölümü, Eğitimde Ölçme ve Değerlendirme A.B.D., 06500 Teknikokullar / Ankara / Türkiye senerbuyukozturk@gmail.com
\end{abstract}

\begin{abstract}
Özet
$\mathrm{Bu}$ çalışmanın amacı okul müdürlerinin değişime yönelik eğilimlerini belirlemeye yönelik bir ölçek geliştirmektir. Bu amaçla daha önce geliştirilmiş değişime açıklık tutum ölçeği ve değişimde bireylerin kişilik özelliklerini belirleyen beş teorik boyutta yazılan maddelerle ölçek oluşturuldu. Ölçek, ilköğretim ve ortaöğretim kurumlarında görev yapan ve gönüllü olarak çalışmaya katılan 284 yöneticiye uygulanmıştır. Açımlayıcı faktör analizi ölçeğin dört faktörden oluştuğunu göstermiştir. Değişimde girişimcilik, değişimin yararına inanma, değişime direnme ve statükoyu koruma (değişimden kaçınma) olarak adlandırılan faktöryel yapı, doğrulayıcı faktör analizi sonuçlarıyla da desteklenmiştir. Ölçek puanlarının güvenirliği için hesaplanan

* Sorumlu Yazar. Tel:+90 3122028234 E-posta: senerbuyukozturk@gmail.com

(C) 2011 Kalem Eğitim ve Sağlık Hizmetleri A.Ş. Bütün Hakları Saklıdır ISSN: 2146 - 5606
\end{abstract}


alfa değerleri .67 ile .91 arasında değişmektedir.

Anahtar Kelimeler: Değişim; Müdür; Yönelimler.

\title{
Change Tendencies Scale Development
}

\begin{abstract}
The purpose of this study is to develop a scale to measure school principals' tendencies toward change. Having reviewed the earlier literature about openness to change, a five factor had been pre-established and items were written accordingly. The scale was administered to 284 administrators working at primary and secondary schools. Exploratory factor analysis revealed four factors: Enterprenurship in change, believe in the usefulness of change, resistance to change, and keeping the status quo, which were supported by the confirmatory factor analysis. The reliability alpha scores changed from .67 to .91 .
\end{abstract}

Key Words: Change; Principal; Tendencies.

\section{Giriş}

Değişme nedir? Kimler neden ve nasıl değişir? Değişmemek mümkün mü? Bu sorular felsefi dayanakları dikkate alınarak cevaplanmaya çalışılmakta, birey ile yönetim ve örgüt boyutlarında tartışılmakta ve bu konuda bilgi üretilmektedir. Değişme, bütün nesne ve olayların her türlü devimi ve etkileşmeyi, bir durumdan bir başka duruma her türlü geçişi dile getiren en genel varoluş biçimi (www.tdk.gov.tr) olarak ifade edilmektedir. Değişme kavramı obje ya da bireylerin mevcut durumlarında özlenen bir farklılaşma (Balc1, 2005) olarak görülmekte ve bir bütünün ögeleri ile ögeler arası ilişkilerin öncesine oranla nicel ve nitel olarak farklılık-ayrılık göstermesi olarak tanımlanmaktadır (Balcı, 2005; Demirtaş ve Güneş, 2002). Tezcan (1990) değişme kavramını, önceki durum ya da davranıştan farklılaşma biçiminde açıklamaktadır. Yazar, değişmede bir sistemin başlangıçtaki biçiminden farklı bir biçime dönü- 
şerek biçim değiştirdiğini, toplumlarda ve insanlardaki başkalaşmaların ve farklılaşmaların değişim olarak nitelenebileceğini belirtmektedir. Öte yandan değişmenin ileri ya da geri hiçbir doğrultuyu ifade etmediği, yenileşme yönünde olduğu gibi eskileşme yönünde de olabileceğine dikkat çekilmektedir (Başaran, 1989; Tezcan, 1990).

Değişim süreci ve değişimle ilgili farklı araştırmalar yapılmaktadır. Son yı1larda özellikle örgütlerin ve bireylerin değişime karşı tutumları onların değişime açık olup olmamaları veya değişime karşı hazır olma tutum ölçekleriyle farklı ülkelerde çalışılmıştır. Bu çalışmalardan bazıları ölçek geliştirme çalışmalarıdır (Bkz., Kwahk \& Lee, 2008; Saldana, Chapman, Henggler, Rowland, 2007; Lai \& Ong, 2010; Mrayyan, Modallal, Awamreh, Atoum, Abdullah \& Suliman, 2008; Littell \& Girvin, 2005; Fuller ve ark. 2007; Lehman, Greener \& Simpson, 2002; Susanto, 2008). Okul yöneticilerinin değişime yönelik tutumları değişime açık olma tutum ölçeğiyle çalışılmıştır (Kurşunoğlu ve Tanrıöğen, 2009; Kondakçı, Zaim ve Çalışkan, 2010). Değişime ilişsin tutumlar genellikle duyuşsal, bilişsel ve davranışsal boyutlarda ölçülmektedir. Kurşunoğlu ve Tanrı̈̈ğen (2009) çalışmasında okul müdürlerinin ve öğretmenlerin öğretimsel liderlik algıları ile değişime karşı tutumları arasında orta düzeyde bir ilişkinin olduğu görülmüştür. Öğretmenlerin bakış açısına göre, onların müdürlerinin öğretimsel liderlik davranışları ile öğretmenlerin değişime karşı pozitif bir ilişki mevcuttur.

Klecker ve Loadman (1999)'in çalışmasında okul müdürlerinin değişme karşı açık olup olmamalarını bilişsel, davranışsal ve duyuşsal boyutta incelemiştir. Bu çalışmada davranışsal boyut ve bilişsel boyut ve bu boyutlar ile toplam puanı arasında yüksek pozitif bir korelasyon bulunurken, duyuşsal boyut ile bilişsel, davranışsal ve toplam puan arasinda negatif korelasyon bulunmuştur. Dolayısıyla analizler toplam puan üzerinden değil, alt boyutlar üzerinden yürütülmüştür. Ayrıca araştırma- 
cıların cinsiyeti, deneyimleri, okul türlerinde tek yönlü varyans analizi sonucunda anlamlı bir fark bulunmamıştır.

Saban (1999) öğrenen okulda sistematik değişim makalesinde sistematik okul değişimindeki insan faktörüne vurgu yapmıştır. Schlechty’nin (1993) çalışmasında eğitimde yeniden yapılanma sürecine öncülük edecek okul liderlerinin, insanların değişime karşı aynı tavrı sergilemeyeceğini bilmeleri ve bu duruma da hazırlıklı olmaları gerektiğini vurgular. Schletchty’ye (1993) göre yeniden yapılanma sürecinde temelde beş farklı tutum sergileyen beş farklı insan tipi vardır. Bunlar kaşifler, öncüler, göçebeler, statükocular ve sabotajcılardır (Akt. Saban, 1999).

Havelock ve Zlotolow' a göre (1995), değişism sürecinde, süreci etkileyen dört önemli kişi veya kişiler vardır. Bunlar liderler, lider olmayanlar, sistem dişındakiler ve direnç gösterenlerdir. Havelock ve Zlotolow (1995) değişim sürecinde özellikle liderin değişim ajanı rolüne vurgu yapmıştır. Ancak liderin yanı sıra alt kademelerde görev alacak değişim ajanının rollerini de açıklamaktadır.

Değişim sürecinde ve değişimin yönetiminde liderlik önemlidir (Snowden ve Gorton, 1998; Havelock ve Zlotolow, 1995; Erdoğan, 2002). Schletchty'ye (1993) göre, okul liderleri tarafından bilinmesinde kritik öneme sahip bu nokta, bu insan tiplerinin her birinin farklı türde beceriler geliştirmeye ve farklı türde yönetimsel desteğe ihtiyaçları olduğudur. Değişim planlanırken, hatta değişim sürecinde örgüttekilerin değişime ilişkin eğilimleri önemlidir. Yöneticiler bu eğilimleri bilirlerse uygun ve etkili değişim stratejileri geliştirip uygulayabilirler. Özellikle Türk eğitim sistemi gibi merkezi bir sistemde değişim öncesi okul müdürlerinin eğilimlerinin saptanması, değişim sürecini etkili yönetmeyi getirebilecektir. Bu çalışmanın amacı da okul müdürlerinin değişim eğilimlerini belirlemeye yönelik bir ölçek geliştirmektir.

Türk eğitim sistemi içinde sürekli değişimler gerçekleşmekte- 
dir. Bu değişimlerde uygulamanın başında bulunan okul müdürlerinin rolleri, değişim algılamaları ve değişimi yönetmeleri önemlidir. Okul müdürlerinin değişsimi yönetmede sadece teknik yeterlik değil tutum ve davranışları da önemlidir. Dolayısıyla literatüre bakıldığında okul müdürlerinin değişime olan tutumları, hazır olma durumları ve değişime açık olup olmamaları farklı ölçeklerle belirlenmiştir. Bu çalışmalarda genellikle müdürlerin ve öğretmenlerin tutumları bilişsel, davranışsal ve duyuşsal boyut üzerinden açıklanmaktadır. Oysaki okul müdürlerinin ve öğretmenlerin değişime karşı tutumlarının dışında onların değişime karşı yönelimleri ve eğilimleri bulunmaktadır ve bu her eğilim veya yönelimin içinde bu boyutlar barınmaktadır. Bu çalışmada da Türk eğitim sisteminde okul gelişiminde ve değişiminde önemli yerleri olan okul müdürlerinin değişime ilişkin eğilimlerini belirlemeye yönelik ölçek geliştirilmeye çalışılmıştır.

\section{Yöntem}

\section{Çalışma grubu}

Araştırma, ilköğretim ve ortaöğretim kurumlarında görev yapan ve gönüllü olarak çalışmaya katılan 284 yöneticiden oluşmaktadır. Hedef gruba, Millî Eğitim Bakanlığınca Ankara, Kayseri, Van ve Samsun'da okul yöneticileri için düzenlenen hizmetiçi eğitim kurslarında ulaşılmıştır. Araştırmaya katılan yöneticilerin \% 63’ü (n=179) ilköğretim, \% 30 'u (n=86) ortaöğretimde yöneticilik yapmakta olup, 19 kişi yöneticilik yaptığ 1 okulu belirtmemiştir. Yöneticilerin \% 8’i (n=23) kadın, \% 90’1 $(n=254)$ erkektir. Yöneticilerden 7'si cinsiyetini belirtmemiştir. Yöneticilik kıdemi 5 yıl ve daha az olanların oran1 \% 34'tür (n=96). Aynı oran 10-15 yıl kıdem için \% 39 (n=111), 16 ve daha fazla kıdem için \% 24 (n=68)’tür. Grubun \% 3’ü $(\mathrm{n}=9)$ yöneticilik kıdemini belirtmemiştir. Yöneticilerin $\%$ 8'i (n=22) önlisans, \% 68'i $(n=193)$ lisans ve \% 18'i $(n=52)$ lisans-üs- 
tü eğitime sahiptir. Grubun \% 6’s1 (n=17) eğitim düzeyine ilişkin bilgi vermemiştir.

\section{Araç}

Değişim Eğilimleri Ölçeği (DEÖ) ilköğretim ve ortaöğretim müdürlerinin değişime ilişkin eğilimlerini belirlemek amacıyla geliştirilmiştir. $\mathrm{Bu}$ eğilimler içinde duygu, düşünce ve davranışlar yer almaktadır. Ö1çeğin geliştirilmesinde Crocker ve Algina (1986) ve Cronbach (1984)'ın önerileriyle tutarlı olarak şu süreçler izlenmiştir:

1. Test ile ölçülecek özelliklerin belirlenmesi: Değişimde eğilimler ölçeğini hazırlarken, Dunham ve arkadaşlarının (1989) geliştirdiği örgütsel kültürde değişim envanterini okul müdürlerine uyarlayan Klecker ve Laodaman (1999) bilişsel, duyuşsal ve davranışsal boyutlarını kapsayan ölçekle, Schletchty'nin (1993) yeniden yapılanma sürecinde temelde beş farklı tutum sergileyen beş farklı insan tipi olarak teorik olarak vurguladığı kaşifler, öncüler, göçebeler, statükocular ve sabotajcilar (Akt. Saban, 1999) dikkate alınmıştır.

2. Ölçekte yer alacak maddelerin yazımı. Ölçekte yer alacak maddelerin yazımında, a) yapılan önceki çalışmalardan (Klecker ve Laodaman, 1999; Schletchty, 1993) , b) uzman görüşünden, c) hedef kitle olan okul müdürlerinin görüşlerinden yararlanılmıştır. Ölçekte başlangıçta toplam 48 madde yazılmıştır. Katılımcıların ifadelere katılma düzeyleri için "hiç katılmıyorum, "katılmıyorum", "kararsızım", "katılıyorum" ve "tamamen katıliyorum" seçeneklerinden oluşan Likert tipi beşli derecelendirme ölçeği kullanılmıştır. Olumlu ifadelerde cevaplar "hiç katılmiyorum"dan "tamamen katılıyorum"a doğru "1"den "5"e doğru, olumsuz ifadeler için tersi kodlama ile puan verilmiştir. Ölçekten elde edilen yüksek puan, değişime olan olumlu eğilimi göstermektedir

3. Uzman görüşünün alınması ve ölçeğin yeniden gözden geçirilmesi. Ölçeğin taslak formunda yer alan maddelerin uygunluğu, konu alanına aşina olan beş uzman tarafindan incelenmiştir. Uzmanlardan taslak formda yer alan her bir 
maddeyi tanımlanan özelliği ölçmedeki yeterliğini, hem nitelik hem de nicelik olarak değerlendirmelerini, düzeltme önerilerini maddeler üzerinde belirtmelerini, varsa yeni madde önerilerini de yazmaları istenmiştir. Uzmanlardan gelen görüşler sonucunda bir madde ölçekten çıkarıldı ve bazı maddelerde değişikliğe gidildi.

4. Ön uygulama öncesi küçük grup üzerinde uygulama yapılması. DEÖ taslak formu, maddelerin ve açıklamaların anlaşılırlığı ve uygulama süresi hakkında geri bildirim almak amacıyla form 10 yöneticiye uygulanmıştır. DEÖ'yü cevaplandıran kişilerle uygulamanın bitiminde görüşme yapılarak açıklamaların ve maddelerdeki ifadelerin ve cevaplama ölçeğinin anlaşılırlığı hakkında ne düşündükleri sorulmuştur. Oldukça sınırlı sayıda (3 madde) madde için sözcük ve cümle yapısında küçük düzeltmeler yapılmış ve ölçek geniş grupta uygulamaya hazır hâle getirilmiştir.

5. Uygulama ve psikometrik analizlerin yapilmasi. Uygulamalar belirlenen örneklem üzerinde posta yoluyla gerçekleştirilmiştir. $\mathrm{Bu}$ aşama, ölçeğin büyük grupta uygulanması ve psikometrik özellikleriyle ilgili olarak geçerlik ve güvenirlik analizlerinden oluşmuştur.

\section{Analiz}

DEÖ’nün yapı geçerliği açımlayıcı faktör analizi (AFA) ve doğrulayıcı faktör analizi (DFA) kullanılarak incelenmiştir. AFA, değişkenler arasındaki ilişkilerden hareketle az sayıda kavramsal olarak anlamlı yeni değişkenler, faktörler bulmayı, ölçülen özellikle ilgili kuramsal bir model üretmeye odaklıdır. Buna karşılık DFA, ampirik olarak keşfedilen ya da kuram temelinde uzman kanısına dayalı olarak oluşturulan ölçme modelinin verilerle, gerçekle uyumunun incelenmesinde kullanılır (Büyüköztürk, 2002, Kline, 1994; Stevens, 1996; Tabachncik ve Fidell, 2001). Değişim eğilimleri ölçmeye odaklı ölçek geliştirme çalışmaları incelendiğinde ölçeklerin faktörleri arasında dikkate değer ilişki olmadığı görülmüştür. Araştırmacılar geliştirmekte oldukları ölçek için de fak- 
törler arasında dikkate değer ilişkiler olmayacağı kabulünden hareketle AFA'da varimax dik döndürme yöntemini kullanmışlardır.

Çalışmada DEÖ’nün AFA ile belirlenen dört faktörlü yapısının geçerliğine ilişkin ek kanıt elde etmek amacıyla aynı veri yapısı üzerinde DFA uygulanmıştır. Burada amaç, dört faktörlü ölçme modelinin toplanan verilerle ne derece uyum gösterdiğini incelemektir. DFA'da modelin geçerliliğini değerlendirmek için çok sayıda uyum indeksi önerilmekle birlikte bu çalışmada, literatürde (Cole, 1987; Sümer, 2000) sık kullanıldığ 1 görülen Ki-Kare Uyum Testi $\left(\chi^{2}\right)$, İyilik Uyum İndeksi (GFI), Düzeltilmiş İyilik Uyum İndeksi (AGFI), Ortalama Hataların Karekökü (RMR/RMS), Yaklaşık Hataların Ortalama Karekökü (RMSEA), Karşılaştırmalı Uyum İndeksi (CFI), Normlaştırılmış Uyum İndeksi (NFI) ve Normlaştırılmamış Uyum İndeksi (NNFI) kullanılmıştır. Literatürde, DFA ile hesaplanan ( $\left.\chi^{2} / \mathrm{sd}\right)$ oranının 3'ten küçük; GFI, AGFI, NFI ve NNFI değerlerinin 0.90'dan büyük; RMS ve RMSEA değerlerinin ise 0.05 'ten düşük çıkması modelin verilerle uyumlu olduğu şeklinde yorumlanmaktadır (Jöreskog ve Sorbom, 1993; Marsh ve Hocevar, 1988).

\section{Bulgular}

\section{DEÖ’nin Faktör Yapısı}

Veri yapısının faktör analizi için uygunluğu için hesaplanan KMO değeri .88'dir. DEÖ’nün faktör yapısını belirlemek amacıyla açımlayıcı faktör analizi uygulandı. Ölçeğin faktörlerin birbirinden bağımsız olmayacağına, aralarında ilişki olabileceğine yönelik öngörü nedeniyle analizde eğik döndürme (oblimin) yöntemi kullanılmıştır. AFA’nın ilk sonuçlarına göre faktör yük değerleri .30'dan düşük olan yedi madde ölçekten çıkartılmış ve analiz tekrarlanmıştır. Yapılan faktör analizi sonuçları ölçeğin dört faktörden oluştuğunu göstermiştir. AFA sonuçları Tablo 1'de verilmiştir. 
Tablo 1. DYÖ AFA sonuçları

\begin{tabular}{|c|c|c|c|c|c|}
\hline Faktör/Item & Faktör 1 & Faktör 2 & Faktör 3 & Faktör 4 & Ortaklar Varyans \\
\hline \multicolumn{6}{|l|}{ Değişimde Girişimcilik } \\
\hline M26 & .68 & & & & .45 \\
\hline M30 & .66 & & & & .55 \\
\hline M39 & .66 & & & & .44 \\
\hline M23 & .65 & & & & .54 \\
\hline M24 & .63 & & & & .40 \\
\hline M37 & .63 & & & & .45 \\
\hline M40 & .61 & & & & .39 \\
\hline M47 & .60 & & & & .38 \\
\hline M33 & .59 & & & & .39 \\
\hline M22 & .57 & & & & .42 \\
\hline M32 & .48 & & & & .26 \\
\hline M44 & .44 & & & & .29 \\
\hline M42 & .43 & & & & .23 \\
\hline M20 & .42 & & & & .37 \\
\hline \multicolumn{6}{|l|}{ Değişime Direnç } \\
\hline M36 & & .74 & & & .55 \\
\hline M27 & & .67 & & & .45 \\
\hline M34 & & .64 & & & .42 \\
\hline M48 & & .60 & & & .40 \\
\hline M43 & & .59 & & & .44 \\
\hline M45 & & .58 & & & .36 \\
\hline M25 & & .57 & & & .33 \\
\hline M41 & & .54 & & & .44 \\
\hline M28 & & .51 & & & .29 \\
\hline M21 & .20 & .50 & & & .29 \\
\hline M46 & & .50 & & & .37 \\
\hline \multicolumn{6}{|l|}{ Değișimin Yararına İnanma } \\
\hline M10 & & & .82 & & .65 \\
\hline M11 & & & .78 & & .70 \\
\hline M03 & & & .75 & & .55 \\
\hline M09 & & & .73 & & .60 \\
\hline M05 & & & .71 & & .47 \\
\hline M15 & & & .70 & & .59 \\
\hline M06 & & & .69 & & .57 \\
\hline M02 & & & .66 & & .45 \\
\hline M14 & .26 & & .65 & & .58 \\
\hline M12 & .24 & & .61 & & .56 \\
\hline M18 & .29 & & .58 & & .57 \\
\hline M08 & & & .45 & & .27 \\
\hline \multicolumn{6}{|l|}{ Statükoyu Koruma } \\
\hline M13 & & & & .68 & .50 \\
\hline M16 & & & & .67 & .56 \\
\hline M07 & & & -.25 & .54 & .47 \\
\hline M04 & & & & .50 & .28 \\
\hline Özdeğer & 9.71 & 3.91 & 2.99 & 1.69 & \\
\hline Açılklanan Varyans (\%) & 23.68 & 9.53 & 7.29 & 4.13 & Toplam =44.63 \\
\hline \multicolumn{6}{|c|}{ Not: Tabloda .20'den düşük yük değerleri gösterilmemiştir. } \\
\hline
\end{tabular}

AFA ile belirlenen dört faktörü adlandırmak amacıyla madde içerikleri incelenmiş ve uzman görüşü alınmıştır. Sonuçta, birinci faktör değişimde girişimcilik, ikinci faktör değişime direnç, üçüncü faktör 
değişimin yararına inanma ve dördüncü faktör statükoyu koruma (değişimden kaçınma) olarak adlandırılmıştır. Dört faktör birlikte toplam varyansın \% 44.63'nü açıklamaktadır.

DEÖ’nün AFA ile belirlenen dört faktörlü yapısının geçerliğine ilişkin ek kanıt elde etmek amacıyla aynı veriler üzerinde DFA yapılmıştır. Yapılan ilk DFA modifikasyon değerlerine bakıldığında "M02 ve M03" ile "M09 ve M11" madde çiftlerinin hataları arasında ilişki olduğu görülmüştür. Anılan ilişkiler modele eklenerek tekrarlanan analize ilişkin path diyagramı Şekil 1'de verilmiştir.

DFA ile hesaplanan uyum istatistikleri şunlardır: $\chi^{2}(\mathrm{sd}=771)=1316.63$, $\left(\chi^{2} / \mathrm{df}\right)=1.71 \mathrm{GFI}=0.81, \mathrm{AGFI}=0.79, \mathrm{RMSEA}=0.05, \mathrm{RMS}=0.05, \mathrm{CFI}=0.97$, $\mathrm{NFI}=0.93$ ve $\mathrm{NNFI}=0.97$. Dört faktörden oluşan DEÖ ölçme modelinde madde ile gizil değişkeni arasında hesaplanan standart katsayılar 0.36 ile 0.70 arasında değişmekte olup, .01 düzeyinde manidardır. Faktörler (gizil değişkenler) arasında hesaplanan standart katsayılar ise 0.30 ile 0.61 arasında değişmektedir.

DEÖ faktör puanlarına ait betimsel istatistikler Tablo 2'de verilmiştir.

Tablo 2. DYÖ faktör puanları için betimsel istatistikler

\begin{tabular}{|c|c|c|c|c|c|}
\hline Faktör & $\begin{array}{c}\text { Madde } \\
\text { Sayısı }\end{array}$ & Ortalama & $\begin{array}{c}\text { Standart } \\
\text { Sapma }\end{array}$ & $\begin{array}{c}\text { En Düşük } \\
\text { Puan }\end{array}$ & $\begin{array}{c}\text { En } \\
\text { Yüksek } \\
\text { Puan }\end{array}$ \\
\hline 1. Değişimde Girişimimcilik & 14 & 55.57 & 6.28 & 36 & 70 \\
\hline 2. Değişime Direnç & 11 & 42.32 & 6.71 & 11 & 55 \\
\hline 3. Değişimin Yararına İnanma & 12 & 50.53 & 6.67 & 19 & 60 \\
\hline 4. Statükoyu Koruma & 4 & 15.97 & 2.91 & 4 & 20 \\
\hline
\end{tabular}

$* \mathrm{P}<.05 \quad * * \mathrm{p}<0.01$

Buna göre ortalama puan değişimde girişimcilik faktörü için 55.57, değişimde direnç faktörü için 42.32, değişimin yararına inanma faktörü için 50.53 ve statükoyu koruma için 15.97 'dir. 


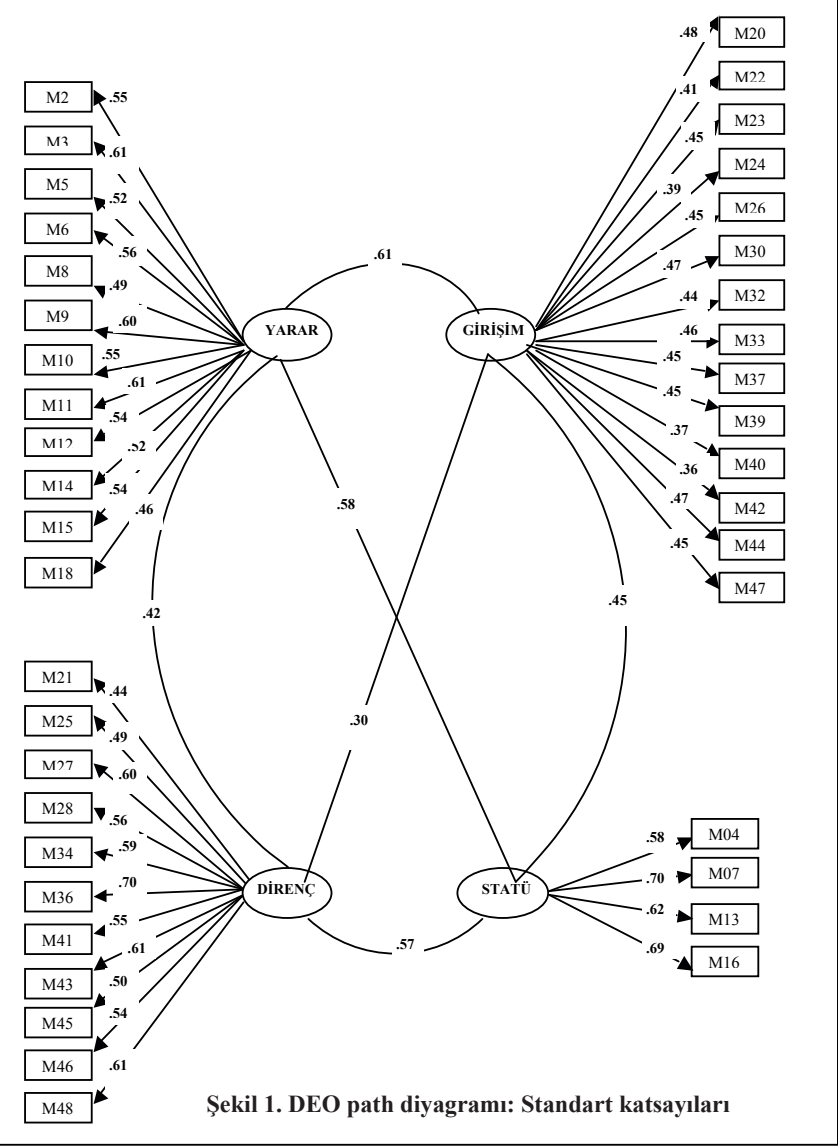

\section{Güvenirlik}

DEÖ puanları için hesaplanan alfa güvenirlik katsayısı değişimin yararına inanma faktörü için .91, değişimde girişimcilik faktörü .86, değişime direnç faktörü için .82 ve statükoyu koruma faktörü için .67'dir. Ölçek maddelerinin yöneticileri değişim eğilimleri davranışları bakımından ne derece ayırt ettiğine ilişkin her bir faktör için hesaplanan düzeltilmiş madde-toplam korelasyonları .34 ile .79 arasında değişmektedir (Tablo 3). 
Tablo 3. DYÖ madde analizi sonuçları

\begin{tabular}{|c|c|c|c|}
\hline Faktör/Madde No & $\begin{array}{c}\text { Düzeltilmiş } \\
\text { Madde-Toplam } \\
\text { Korelasyonu }\end{array}$ & Faktör/Madde No & $\begin{array}{c}\text { Düzeltilmiş } \\
\text { Madde-Toplam } \\
\text { Korelasyonu }\end{array}$ \\
\hline Değişimde Girişimcilik & & Değişimin Yararına İnanma & \\
\hline M20 & .47 & M02 & .55 \\
\hline M22 & .54 & M03 & .65 \\
\hline M23 & .64 & M05 & .60 \\
\hline M24 & .54 & M06 & .69 \\
\hline M26 & .56 & M08 & .45 \\
\hline M30 & .66 & M09 & .71 \\
\hline M32 & .37 & M10 & .72 \\
\hline M33 & .51 & M11 & .79 \\
\hline M37 & .58 & M12 & .65 \\
\hline M39 & .53 & M14 & .67 \\
\hline M40 & .53 & M15 & .71 \\
\hline M42 & .39 & M18 & .66 \\
\hline M44 & .45 & & \\
\hline M47 & .53 & & \\
\hline Değişime Direnç & & Statükoyи Koruma & \\
\hline M21 & .37 & M04 & .34 \\
\hline M25 & .44 & M07 & .54 \\
\hline M27 & .55 & M13 & .42 \\
\hline M28 & .42 & M16 & .56 \\
\hline M34 & .55 & & \\
\hline M36 & .63 & & \\
\hline M41 & .50 & & \\
\hline M43 & .55 & & \\
\hline M45 & .41 & & \\
\hline M46 & .48 & & \\
\hline M48 & .47 & & \\
\hline
\end{tabular}




\section{Tartışma ve Öneriler}

Bu çalışmada okul müdürlerinin değişime yönelik eğilimlerini belirleyecek bir ölçek geliştirilmiştir. Geliştirilen ölçek dört faktörlüdür. Dört faktörlü yapı AFA ile belirlenen dört faktörlü yapı, daha sonra DFA ile de incelenmiş ve hesaplanan uyum istatistikleri yöntemde belirtilen ölçüt değerleri karşıladığ1 görülmüştür. Buna göre ölçeğin model-veri uyumunun iyi olduğu değerlendirilmiştir. Ölçek puanlarının güvenirliğine ilişkin hesaplanan alfa değeri statükoyu koruma faktörü için .67 bulunmuştur. Bu değer görece düşük olmakla birlikte anılan faktörde sadece dört maddenin bulunması, maddelerin gizil değişkenleriyle verdiği standart katsayıların .50 ve ham puanlar üzerinde hesaplanan düzeltilmiş madde-toplam korelasyonlarının .30’un üzerinde olması bu alt ölçeğin akademik çalışmalarda kullanılabileceğini göstermiştir. Öte yandan ölçeğin diğer üç faktörü için hesaplanan alfa değerleri .80’nin üzerinde olup oldukça tatmin edicidir.

Ölçeğin faktörleri, değişimde girişimcilik, değişimin yararına inanma, değişime direnme ve statükoyu koruma (değişimden kaçınma) olarak adlandırılmıştır. Bu boyutlar Dunham ve arkadaşlarının (1989) geliştirdiği örgütsel kültürde değişim envanterini okul müdürlerine uyarlayan Klecker ve Laodaman (1999) bilişsel, duyuşsal ve davranışsal boyutlarını kapsayan ölçekle, Schletchty’nin (1993) yeniden yapılanma sürecinde temelde beş farklı tutum sergileyen beş farklı insan tipi olarak teorik olarak vurguladığı kaşifler, öncüler, göçebeler, statükocular ve sabotajcılar ölçeğinin birleşmesiyle oluşan yeni farklı boyutlardır.

DEÖ’nün bu ölçekle okul müdürlerinin değişime ilişkin nasıl bir eğilim göstereceği belirlenebilir. Ayrıca bu ölçek öğretmenler için de uyarlanarak öğretmenlerin değişime yönelimleri de belirlenebilir. $\mathrm{Bu}$ ölçek kullanılarak Türkiye genelinde okul müdürlerinin değişim eğilimlerini belirleyecek kapsamlı bir çalışma yapılabilir. 


\section{Kaynakça}

Balc1, A. (2005). Eğitim Yönetimi Sözlüğü. Tek Ağaç Yayınevi.

Başaran, İ.E. (1989). Yönetim. Gül Yayınevi.

Büyüköztürk, Ş. (2002). Faktör analizi: Temel kavramlar ve ölçek geliştirmede kullanımı. Eğitim Yönetimi Dergisi, 470-483

Cole, D.A. (1987). Utility of confirmatory factor analysis in test validation research. Journal of Consulting and Clinical Psychology, 55, 1019-1031.

Croceker, L. ve Algina, J. (1986). Introduction to classical and modern test theory. Fort Worth: Holt, Rinehart and Winston Inc.

Cronbach, L. J. (1984). Essentials of psychological testing (4th ed), New York: Harper Row

Demirtaş, H. ve Güneş, H. (2002). Eğitim Yönetimi ve Denetimi Sözlüğü, Anı Yayıncılık.

Dunham, R.B., Grube, J. A., Gardner, D. G., Cummings, L.L., ve Pierce, J.L. (1989). The inventory of change in organizational culture. Madison: Authors.

Erdoğan, İ. (2002). Eğitimde Değişim Yönetimi. Ankara: Pegem A Yayıncılık.

Fullar, B. E., Rieckmann, T., Nunes, E.V., Miller, M., Arfken, C., Edmundson, E., ve McCarthy, D. (2007). Organizational Readiness for Change and opinion toward treatment innovations. Journal of Substance Abuse Treatment, 33, 183-192.

Havelock, R.G. ve Zlotolow, S. (1995). The change agent's guide. (2nd ed.). New Jersey: Engellwood Cliffs.

Jöreskog, K.G. ve Sörbom, D. (1993). LISREL 8: Structural equation modeling with the SIMPLIS command language. Hillsdale, NJ: Lawrence Erlbaum Associates Publishers

Jöroskog, K.G. ve Sörbom, D. (1986). Lirsel VI: Analysis of linear structural relationships by maximum likelihood, instrumental variables, and least squares methods. Mooresville, IN: Scientific Software.

Klecker, B.M. ve Loadman, W.E. (1999). Measuring Principals' openness to change on three dimensions: Affective, cognitive and behavioral. Journal of Instructional Psychology, 26(4), 213-226.

Kline, P. (1994). An easy guide to factor analysis. New York: Routledge. 
Kondakçı, Y., Zaim, M. ve Çalışkan, F. (2010). Okul Yöneticilerinin Değiş̧ime hazır olma tutumlarının okulun öğretim düzeyi, yöneticilerin deneyimi ve okul büyüklüğü bağlamında incelenmesi. Inönü Üniversitesi Eğitim Fakültesi Dergisi, 11(29), 155-175.

Kurşunoğlu, A. ve Tanrı̈ğgen, A. (2009). The Relationship between teachers' perceptions towards instructional leadership behaviors of their principals and teachers' attitudes towards change. Procedia Social Sciences, WCESS 2009.

Kwahk, K. Y., ve Lee, J.M. (2008). The role of readiness for change in ERP implementation: theoretical bases and emprical validation. Information and Management, $45,475-481$.

Lai, J-Y. ve Ong, C-S. (2010). Assesing and managing employees for emracing change: A multiple-item scale to measure employee readiness for e-business. Technovation, 30, 76-85.

Lehman, W.E.K., Greener, J.M. \& Simpson, D.D. (2002). Assessing organizational readiness for change. Journal of Substance Abuse Treatment, 22, 197-209.

Littell, J. H. ve Girvin, H. (2005). Caregivers' readiness for change: predictive validity in a child welfare sample. Child Abuse \& Neglect, 29, 59-80.

Mars, H. W. ve Hocevar, D. (1988). A new more powerful approach to multitrait-multimethod analyses: Application of second-order confirmatory factor analysis. Journal of Applied Psychology, 73 107-117.

Mrayyan, M. T., Modallal, R., Awamreh, K., Atoum, M., Abdullah, M. ve Suliman, S. (2008). Nurse Education in Practice. 8, 120-128.

Saban, A. (1999). Öğrenen okulda sistematik değişim. Ĕgitim Yönetimi, 19, 393-409.

Saldana, L., Chapman, J. E., Henggeler, S. W., Rowland, M. D. (2007). The organizational readiness for change scale in adolesent programs: Criterion validity. Journal of Substance Abuse Treatment,33, 159-169.

Schlechty, P.C. (1993). On the frontier of school reform with Trailblazers, Pineers, and Settlers. Journal of Staff Development, 14, 46-51. (Akt. A.Saban, 1999). Öğrenen Okulda Sistematik Değişim. Eğitim Yönetimi,19, 393-409.

Snowden, P.E. \& Gorton, R.A. (1998). School Leadership \& Administration: Important Concepts, Case Studies \& Simulations. McGrow Hill. 
Stewens, J. (1996). Appied multivariate statistics for the social science (3rd ed). New Jersey: Lawrence Erlbaum Associates.

Susanto, A.B. (2008). Organizational Readiness for Change: A case study on Change Readiness in a Manufacturing Company in Indonesia. International Journal of Management Perspectives. 2(1), 50-61.

Sümer, N. (2000). Yapısal eşitlik modelleri: Temel kavramlar ve örnek uygulamalar. Türk Psikoloji Yazllarl, 3(6), 49-74

Tabachnick, B. G, ve Fidell, L.S. (2001). Using multivariate statistics (4th ed). Boston: Ally and Bacon.Tezcan, M. (1990). Toplumsal ve kültürel değişim. (2. Bask1). Ankara Üniversitesi Eğitim Bilimleri Fakültesi Yayınları, (164).

Türk Dil Kurumu Sözlügüü. www.tdk.gov.tr. 


\section{Okul Müdürleri İçin Değişim Ĕ̆gilimleri Ölçeği}

\begin{tabular}{|c|c|c|}
\hline $\begin{array}{l}\text { Madde } \\
\text { No }\end{array}$ & $\begin{array}{c}\text { Ters } \\
\text { Madde }\end{array}$ & İfade \\
\hline $1^{*}$ & $\sqrt{ }$ & Değişime direnirim. \\
\hline 2 & & Değişimler okulda daha verimli olmama yardımcı olur. \\
\hline 3 & & Okulumda böylesi değişimlerin olmasını, dört gözle beklerim. \\
\hline 4 & $\sqrt{ }$ & Değişimlerden hoşlanmam. \\
\hline 5 & & Değişimler, okuluma fayda sağlar. \\
\hline 6 & & Değişimler, okulumdaki hoşnut olunmayan durumları gidermemde yardımcı olur. \\
\hline 7 & $\sqrt{ }$ & Değişimlerin, benim okulumda olması beni ürkütür. \\
\hline 8 & & Okulda çalışanların çoğu değişimlerden yarar elde edecektir. \\
\hline 9 & & Değişimlerin gerçekleşmesi için mümkün olan her şeyi yaparım. \\
\hline 10 & & Bu tür değişimleri, okulum için öneririm. \\
\hline 11 & & Değişimleri desteklemek için elimden ne gelirse yaparım. \\
\hline 12 & & Böylesi değişimler üzerine düşünmek bana haz verir. \\
\hline 13 & $\sqrt{ }$ & Değişimlerin çoğu tedirgin edicidir. \\
\hline 14 & & Değişimleri desteklerim. \\
\hline 15 & & Değişimlerden faydalanırım. \\
\hline 16 & $\sqrt{ }$ & Böyle değişimler için düğmeye basmaktan çekinirim. \\
\hline $17^{*}$ & & Başkaları benim değişimi desteklediğimi düşünür. \\
\hline 18 & & $\mathrm{Bu}$ tür değişimler beni harekete geçirir. \\
\hline $19 *$ & & Okuldaki değişimde ihtiyaç duyulacak emek, para ve zamana ilişkin bilgim vardır. \\
\hline 20 & & Bir değişim sürecinde ilk adımı ben atarım. \\
\hline 21 & $\sqrt{ }$ & $\begin{array}{l}\text { Okuldaki öğretmenler benim her şeyden şikâyet eden bir yapımın olduğunu } \\
\text { bilirler. }\end{array}$ \\
\hline 22 & & $\begin{array}{l}\text { Bir değişim sürecinde öğretmenlerime başarılı olacakları konusunda güvence } \\
\text { veririm. }\end{array}$ \\
\hline 23 & & Okulda bir uygulama olduğunda öncülük ederim. \\
\hline 24 & & Bir değişim olduğunda benden ne beklendiğini bilirim. \\
\hline 25 & & Düzgün işleyen bir okulda bir değişikliğe ihtiyaç yoktur. \\
\hline 26 & & Okuldaki değişimde ortaya çıkabilecek belirsizliklerle baş edebilirim. \\
\hline 27 & $\sqrt{ }$ & Okuldaki değişimler beni çok heyecanlandırmaz. \\
\hline 28 & $\sqrt{ }$ & Bu sistemde hiçbir şeyin değişeceğine inanmam. \\
\hline $29 *$ & $\sqrt{ }$ & Değişim her zaman olumlu sonuç vermez. \\
\hline 30 & & Okulumdaki değişimlerde öğretmenlerime rehber olurum. \\
\hline
\end{tabular}




\begin{tabular}{|l|l|l|}
\hline $31^{*}$ & & Değişimi engellemek isteyen öğretmenler önce benden destek almak isterler. \\
\hline 32 & & Okulumdaki öğretmenlerime değişimlerde geleceğin resmini ben çizerim. \\
\hline 33 & & Değiş̧imde belirsizlikle baş etme benim en önemli özelliğimdir. \\
\hline 34 & $\sqrt{ }$ & Her şeyden şikâyet eden bir yapım var. \\
\hline $35^{*}$ & & Her türlü değişimde ilk girişimci ben olurum. \\
\hline 36 & & Okulumdaki öğretmenler benim problem yaratan biri olduğumu bilirler. \\
\hline 37 & & Okuldaki değişim sürecinde öğretmenlerimin duygularını anlayabilirim. \\
\hline $38^{*}$ & & $\begin{array}{l}\text { Bir değişim olduğunda karşışaşı̆̆ım sorunları öğretmenlere yansıtmadan } \\
\text { çözerim. }\end{array}$ \\
\hline 39 & & Değişimin sancılarının neler olacağını önceden tahmin ederim. \\
\hline 40 & & Bir değişim sürecinde duygularımı olumlu olarak yönlendiririm. \\
\hline 41 & $\sqrt{ }$ & Bir değişim olacağı zaman çok gerilirim. \\
\hline 42 & & Bir değişim olduğunda sorunları öğretmenlerle çözerim. \\
\hline 43 & $\sqrt{ }$ & $\begin{array}{l}\text { Bir değişim olduğunda öğretmenler benim gazabıma uğramamak için benden } \\
\text { uzak dururlar. }\end{array}$ \\
\hline 44 & & Bir değişim olduğunda içim kıpır kıpırdır, yerimde duramam. \\
\hline 45 & & Okuldaki öğretmenler bir değişimi engellemek isterlerse onları desteklerim \\
\hline 46 & $\sqrt{ }$ & Değişimin sancılarıyla baş etmek beni yorar. \\
\hline 47 & & Okulumda değişime öncülük edecek öğretmenlerimi güdülerim \\
\hline 48 & $\sqrt{ }$ & Okulumda değişime ihtiyaç olduğunu düşünmüyorum. \\
\hline
\end{tabular}

\section{* Ölçekten çıkartılan maddeler.}

